\title{
Educational disruptions during the COVID-19 crisis in Small Island Developing States: Preparedness and efficacy of academics for online teaching
}

\author{
Isma Seetal ${ }^{1}$ (D) . Sandhya Gunness ${ }^{2}$ - Viraiyan Teeroovengadum ${ }^{2}$
}

Accepted: 3 May 2021 / Published online: 15 May 2021

(c) UNESCO Institute for Lifelong Learning and Springer Nature B.V. 2021

\begin{abstract}
COVID-19 has caused a global rush of universities to transfer their courses online to maintain continuity in student teaching and learning. The study presented in this article investigated the preparedness of academics in Small Island Developing State (SIDS) universities for shifting to emergency online teaching. To examine the impact of preparedness and other factors on the efficacy of academic staff in performing their work duties during the pandemic, the research team collected data from 75 respondents who filled in a questionnaire. In addition, they conducted semi-structured online interviews with a subsample of 5 respondents. They found that most academics had the necessary tools and infrastructure to teach online, including access to reasonably fast internet connections. However, many of them lacked adequate training in applying the use of technology to teaching, which limited their preparedness for developing e-learning activities. Thus, the study found that, insufficient competence in using educational technologies and inadequate university support impacted academics' work efficacy significantly. This impact was less pronounced for staff who had prior online teaching experience, which suggests that their pre-pandemic experiences lessened their dependence on support for online teaching when the sudden need arose. The authors' thematic analysis similarly found academics' uneven familiarity with technology and the need for more "at-the-elbow" technological support during crises to be significant, as well as a need for more leadership to deal with complex situations. Based on their findings, the authors conclude that greater preparedness for online teaching - and thus improved efficacy - might be achieved through a balanced mix of independent learning (by doing) on the part of academic staff and customised and targeted formal professional learning (through training provided by the university).
\end{abstract}

Keywords academic preparedness · online teaching · Small Island Developing States (SIDS) · efficacy · COVID-19 pandemic

Isma Seetal

isma_seetal@hotmail.com; isma.seetal@eagles.cui.edu

Extended author information available on the last page of the article 


\section{Résumé}

Perturbations de l'éducation pendant la crise de la COVID-19 dans les petits États insulaires en développement : degré de préparation et efficacité des universitaires pour enseigner en ligne - La COVID-19 a amené les universités du monde entier à transférer précipitamment leurs cours en ligne afin d'assurer la continuité de l'enseignement et de l'apprentissage pour les étudiants. L'étude présentée dans cet article s'est demandé à quel point les universitaires des universités de petits États insulaires en développement étaient préparés à passer à l'enseignement en ligne dans une situation d'urgence. Pour examiner l'impact du degré de préparation et d'autres facteurs sur l'efficacité du travail du personnel enseignant pendant la pandémie, l'équipe de recherche a recueilli des données auprès de 75 personnes qui ont rempli un questionnaire. En outre, elle a mené des interviews semi-structurées en ligne auprès d'un sous-échantillon de cinq répondants, ce qui lui a permis de conclure que la plupart des universitaires disposaient des outils et infrastructures nécessaires pour enseigner en ligne, notamment d'une connexion Internet suffisamment rapide. Toutefois, bon nombre d'entre eux n'avaient pas été correctement formés à l'utilisation de la technologie pour enseigner. De ce fait, ils ne sont pas pleinement préparés à développer des activités d'e-learning. Ainsi, l'étude a révélé que les universitaires étaient insuffisamment formés à l'utilisation des technologies éducatives et que le soutien inadapté des universités influait considérablement sur l'efficacité de leur travail. Cet impact était moins prononcé chez ceux qui avaient auparavant déjà enseigné en ligne, ce qui indique que cette expérience antérieure à la pandémie les rendait moins dépendants d'un soutien dans ce domaine quand la nécessité du distanciel s'est fait jour de manière urgente. L'analyse thématique des auteurs a également permis de constater que les niveaux d'aisance inégaux des universitaires quant à l'utilisation de la technologie et le besoin d'un soutien technologique «à portée de main » en période de crise pouvaient être importants, de même que la nécessité de plus de leadership pour gérer les situations complexes. S'appuyant sur ces constatations, les auteurs concluent que l'on pourrait mieux préparer à l'enseignement en ligne - ce qui améliorerait l'efficacité - en associant de façon équilibrée l'apprentissage indépendant (par la pratique) du personnel universitaire et un apprentissage professionnel formel, ciblé (au moyen d'une formation proposée par l'université).

\section{Introduction}

The COVID-19 pandemic has wreaked havoc on education systems around the world, becoming the most substantial threat to education since World War II (Atlantis Group 2020). Closures of universities and other higher education institutions across 175 countries and communities have impacted more than 220 million students (Azevedo et al. 2020). ${ }^{1}$ Universities have rushed to transfer their courses online with varied levels of success to ensure a semblance of continuity in student teaching and learning. Research findings emerging from case studies of specialised

\footnotetext{
${ }_{1}^{1}$ This article was drafted in August 2020.
} 
higher education institutions, the academic community across various continents (Bao 2020; Rumbley 2020), webinars from around the world (Weissman 2020) and reports from international organisations discuss emergency online teaching in various regions of the world. However, there is a dearth of research on higher education preparedness in Small Island Developing States (SIDS) during the current health crisis. ${ }^{2}$ To address this gap, we conducted a study focusing on the following research questions:

RQ1: In what ways were academics in SIDS prepared for the transition to remote online teaching?

RQ2: How did preparedness for online teaching affect SIDS academics' efficacy in performing their work duties?

To provide answers to these questions, we analysed SIDS data through a combination of statistical analyses, including principal component analysis (PCA) and multiple linear regressions. Before we present our study, we offer background information on the context of SIDS and a research overview of what preparedness for online teaching in higher education entails and what the characteristics of online instructors are. After providing our mixed methods research design, we present our analyses, findings, implications and concluding remarks.

\section{Context}

The term Small Island Developing States (SIDS) refers to insular, climate-vulnerable small countries with limited resources (in terms of human resources, land, funding, technology and know-how) (Guillaumont 2010), which have attained more freedom in recent decades through "decolonization, the end of bipolarity, democratization, trade liberalization and the digital revolution" (Henrikson 2001, p. 1). However, in terms of their "Networked Readiness Index"3 (Dutta and Jain 2004), it has become apparent that SIDS were not very prepared to exploit ICT innovations to their advantage at the turn of the millennium. Likely reasons for this were being subject to various inhibiting factors such as technology anxiety, costliness of hardware, inequitable access to technology and lack of training that slowed down uptake and deployment of Information Technologies (IT). University administrations elsewhere echo some of these equity concerns related to digital divides and costs of content creation (Jones 2008). The increased implementation of distance and flexible instructional modes (especially in the wake of the current pandemic) will not only have to address equity issues but will also support SIDS in the development

\footnotetext{
${ }^{2}$ Geographically, the group of 58 Small Island Developing States (SIDS) is divided into three subgroups, namely 29 Caribbean island states, 20 Pacific island states, and a conglomerate of 9 island states in Africa, the Indian Ocean, the Mediterranean and the South China Sea (AIMS).

3 “The Networked Readiness Index (NRI) is defined as a nation's or community's degree of preparation to participate in and benefit from information and communication technology (ICT) developments" (Dutta and Jain 2004, p. 3).
} 
of their tertiary education sector; an area in which they have traditionally lagged behind (Chandra 2010). Despite the potential benefits that the use of technology for higher education in SIDS can bring, the lack of leadership has been another inhibiting factor (ibid.).

More recently, Michael Crossley and Terra Sprague (2014) have outlined how the resilience of SIDS and their small scale allow for the impact of successful innovations to be felt across the nation. SIDS have progressed in the prevalence and cost-effectiveness of their ICT networks since the Third International Conference on Small Island Developing States held in Apia, Samoa in September 2014, which focused the world's attention on the need to support the sustainable development of SIDS. ${ }^{4}$ The ICT sector is an important contributor to gross domestic product (GDP) in many SIDS, producing measurable indirect impacts and enabling innovation and entrepreneurship. However, the gains have been jagged, resulting in significant gaps between higher performing and lower performing constituent countries (ITU 2019).

\section{Preparedness for online teaching and characteristics of online instructors}

Online teaching requires careful preparation, ongoing practice, self-efficacy and sound pedagogy. Three decades after the establishment of the World Wide Web, there are now innumerable books, articles, research papers and educational websites providing methods, models, applications, best practices, opportunities, limitations and challenges of using technology to better support learners. However, the existence of this body of resources does not automatically mean it is actually possible for all teachers to put the know-how recorded in those repositories into practice in the event of an emergency shift to online teaching.

\section{Preparedness for online teaching and learning}

Preparedness to shift from face-to-face to online teaching and learning entails prior understanding of how to use the internet and its related tools to create meaningful learning events, activities and assessments. As Martin Weller, Professor of Educational technologies at the Open University UK points out in a blog post published at the beginning of the COVID-19 pandemic in March 2020:

Without the necessary support or development required, in such a small timeframe, it [teaching online with little or no experience] is likely to be frustrating and full of potential errors, which makes educators and students feel vulnerable (Weller 2020).

In a case study of students' perspectives of successful e-learning, David Edris (2020) finds that what prepared students in Florida Public State college for online

\footnotetext{
${ }^{4}$ For more information about the conference, see the dedicated United Nations webpage (UN 2014).
} 
learning was an e-learning orientation course that explained how to use their university's Learning Management System (LMS) and outlined the best practices for learning online. This finding would suggest that for their teaching to be effective, tutors and teaching staff should ideally already be aware of different functionalities and pedagogical opportunities of an e-learning platform before they embark on online teaching. This has already been put into practice for a number of years in Malaysia, where pre-service teachers undergo a well-structured teacher training course that incorporates the teaching of IT skills which subsequently leaves them prepared to integrate online media into their classroom teaching (Fook et al. 2011).

Alternative pedagogies such as authentic e-learning (Herrington et al. 2010) ${ }^{5}$ or project-based learning (Koh et al. 2010) have not been endorsed despite decades of strong research providing evidence that such methods are effective. The "2020 pivot [to online teaching triggered by the COVID-19 pandemic] was not universally successful" (Bonk and Wiley 2020). Chrysi Rapanta et al. note that

Online teaching and learning imply a certain pedagogical content knowledge (PCK), mainly related to designing and organising for better learning experiences and creating distinctive learning environments, with the help of digital technologies (Rapanta et al. 2020, p. 923).

They affirm that the design of learning activities should be

communicated in an accurate and clear manner, have an adequate level of difficulty for students' capabilities and expectations, be related to authentic contexts to increase students' engagement and be accessible to everyone (ibid., p. 937).

Interviews of tutors and evaluators in their study (ibid., pp. 938-939) suggest the necessity of a combination of three types of presence:

(1) social - referring to the various social communication channels that tutors and lecturers must adopt for enhancing immediate student-student and studentteacher interactions;

(2) cognitive - how they would engage the learners to think about the learning content; and

(3) facilitatory - adopting tools that can replicate the face-to face direct instructions and mentoring.

During the first wave of COVID-19, acclaimed e-learning and educational technology professors, technology-enhanced learning evangelists and book authors

\footnotetext{
5 Herrington et al. derive authentic e-learning from authentic learning: "For authentic learning to occur, learners must be engaged in an inventive and realistic task that provides opportunities for complex collaborative activities. Many of the best teachers provide exactly this type of learning experience for their students without necessarily thinking of it as authentic" (Herrington et al. 2010, p. 1). They extend this idea by arguing: "In our view, authentic learning is best executed with powerful computer-based, participatory tools - this is e-learning at its best" (ibid., p. 14).
} 
along with international learning institutions (Bates 2020; Weller 2020; Czerniewicz 2020; Kanwar and Daniel 2020; Bonk and Wiley 2020; Luthra and Mackenzie 2020) consistently posted advice for e-learning novices which were in line with Gilly Salmon's "e-tivities for enabling active and participative online learning by individuals and groups" (Salmon 2013, p. 5). ${ }^{6}$ The posted advices concern online activities which deal with Salmon's five-phase model:

(1) access and motivation;

(2) development of online socialisation;

(3) information exchange;

(4) knowledge construction; and

(5) development of understanding.

Each of these phases include increasing levels of interactivity, which start with high levels of technical support in the first phase (Naylor and Nyanjom 2020) and gradually require less scaffolding from both the technical team and the tutor as learners take on more and more responsibility for their learning. As many studies assert, institutions need to appreciate that educators mostly want to do what is best for students, yet require targeted "at-the-elbow" support ${ }^{7}$ to overcome hurdles presented by the change process (Lackey 2011; Bigatel et al. 2012; Downing and Dyment 2013; Kilgour et al. 2019; Mishra et al. 2020, Hodges et al. 2020).

\section{Characteristics of online instructors}

In an article discussing readiness and resistance in organisational change, Dennis Self and Mike Schraeder (2009) claim that personal factors contributing to resistance to online teaching include personality characteristics, individual needs, and the probable benefits or distress to one's well-being which may be to some extent generational in nature, but can be gradually addressed through training. This is indeed highlighted in many other studies (Mansbach and Austin 2018; Badia et al. 2017; Lane and Lyle 2011), suggesting that gender, age, academic background and online teaching dedication tend to predict adoption of computer-based teaching. Other studies suggest that faculty members who completed certified courses preparing them to teach in blended and online learning environments were better facilitators compared to faculty members who only received on-the-job training (Gurley 2018; Richter and Idleman 2017). Finally, educators who are new to teaching online (Gülbahar and Adnan 2020) might not be adequately ready to support their learners successfully.

Despite the adverse circumstances of the pandemic health crisis, the current situation can provide the opportunity to generate or catalyse change by reforming

\footnotetext{
${ }^{6}$ Conflating "electronic" and "activities", Salmon's e-tivities refer to a "framework for active and interactive online learning" (Salmon 2013, p. 1, italics in original)

7 At-the-elbow support refers to "[t]imely and effective technology professional development support provided to teachers that enable[s] teachers to focus on supporting students rather than troubleshooting technical failures" (Feist and Reid 2017, p. 87).
} 
established organisational structures and policies. Thus, it is worth investigating how higher education institutions and academics in SIDS are maintaining the status quo and ensuring that continuity prevails, even in the face of adversity, a health crisis and educational paradigm shifts.

\section{Method}

Our research team consisted of the first and second authors of this article as well as a research assistant who helped with the transcription of the interviews. The third author was invited to join the team after the review process to help with the statistical analysis. We also consulted an e-learning expert to ensure face validity of our instrument and asked three academics and one non-academic who were not otherwise involved with our study to pretest our questionnaire to check the usability of our online survey. We conducted our study between May 2020 and June 2020 at a time when the COVID-19 pandemic had forced people in many countries around the globe into various forms of social isolation.

After seeking ethical clearance for our study from the University of Mauritius, we recruited participants for our sequential explanatory mixed methods study through convenience and snowball sampling. Members of our research team reached out to contacts in their networks in Mauritius and other parts of the conglomerate of countries comprising Africa, the Indian Ocean, the Mediterranean and the South China Sea (AIMS). ${ }^{8}$ These contacts were, in turn, asked to circulate our request for participation in the study to their colleagues. All participants were academics from various disciplines who worked at universities in SIDS countries across three geographical regions including AIMS. Although convenience sampling primarily recruited participants from SIDS states, particularly from Mauritius in the Indian Ocean, the snowball sampling broadened the scope of participation to include other SIDS countries which were all primarily United Nations Member States except for the US Virgin Islands. The academics were only recruited from universities, excluding other higher education institutions.

\section{Research design}

We selected a mixed methods methodology (see Figure 1) based on the premise that the combination of robust statistical evidence with participants' personal experiences would offer a more comprehensive understanding of a problem of practice than mono-method research (Creswell 2013). Based on the belief that the shift to remote teaching represented a practical issue which rested on real-life experiences and self-efficacy, we adopted a pragmatist stance. As shown in Figure 1, we began

\footnotetext{
8 The nine AIMS countries, all of which are United Nations Member States, are Bahrain, Cabo Verde, Comoros, Guinea-Bissau, the Maldives, Mauritius, São Tomé and Principe, the Seychelles and Singapore,
} 
Figure 1 Mixed methods design

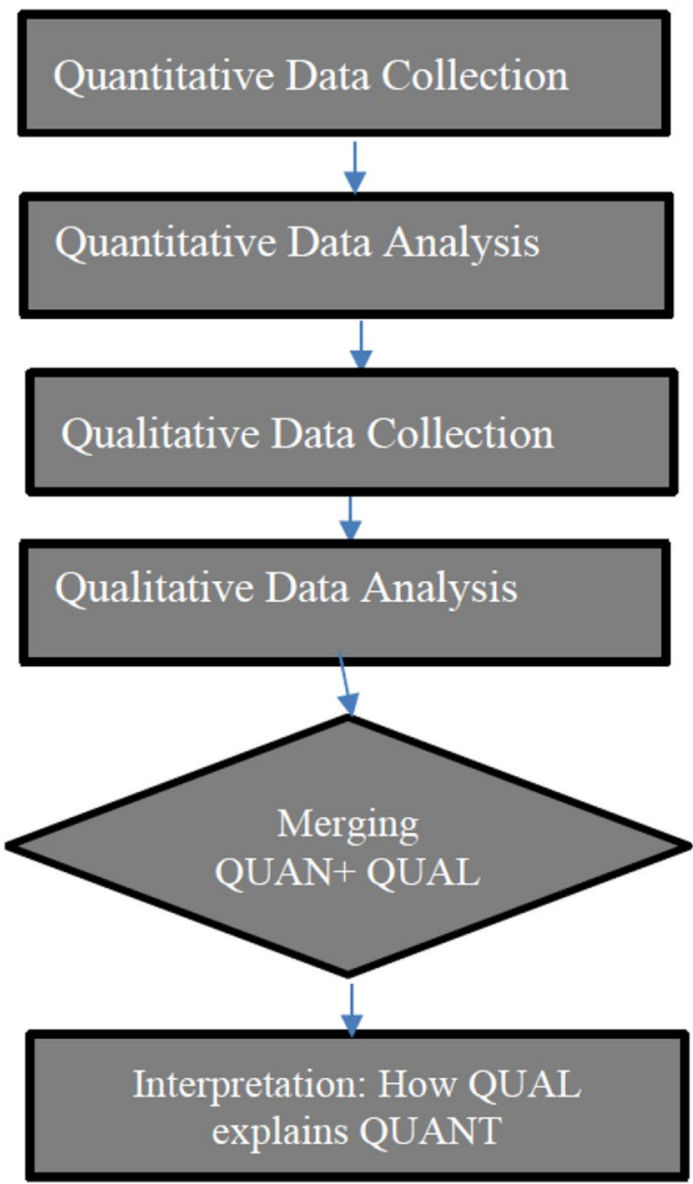

Table 1 Participants' age and number of years of experience

\begin{tabular}{llllllll}
\hline Demographic characteristic & $n$ & $\begin{array}{l}\text { Missing } \\
\text { values }\end{array}$ & $M$ & $M d n$ & $S D$ & Minimum & Maximum \\
\hline Age & 66 & 6 & 45.92 & 44.50 & 10.53 & 26 & 72 \\
$\begin{array}{l}\text { Number of years taught in } \\
\text { higher education }\end{array}$ & 72 & 0 & 15.22 & 15.00 & 9.05 & 1 & 51 \\
$\begin{array}{c}\text { Number of years taught in } \\
\text { current education institution }\end{array}$ & 71 & 1 & 12.34 & 10.00 & 8.56 & 1 & 40 \\
\hline
\end{tabular}

with a leading dominant quantitative strand based on a quasi-experimental approach, and then complemented this with a subsequent qualitative phase. 
Table 2 Participants' demographic characteristics

\begin{tabular}{|c|c|c|c|}
\hline Demographic characteristic & Categories & Frequency & Percentage $(\%)$ \\
\hline \multirow[t]{2}{*}{ Gender $(n=71)$} & Female & 37 & 52.1 \\
\hline & Male & 34 & 47.89 \\
\hline \multirow[t]{8}{*}{ Faculty discipline $(n=72)$} & Agriculture & 1 & 1.40 \\
\hline & Commerce and Management & 8 & 11.10 \\
\hline & Engineering and Technology & 9 & 12.50 \\
\hline & Health and Medical Sciences & 6 & 8.30 \\
\hline & Humanities & 9 & 12.50 \\
\hline & Natural Sciences & 11 & 15.30 \\
\hline & Social Sciences & 21 & 29.20 \\
\hline & Other & 7 & 9.70 \\
\hline \multirow[t]{3}{*}{ SIDS Region $(n=72)$} & AIMS & 45 & 62.50 \\
\hline & Caribbean & 15 & 20.80 \\
\hline & Pacific & 12 & 16.70 \\
\hline \multirow[t]{3}{*}{$\begin{array}{l}\text { Type of higher Education } \\
\text { institution }(n=71)\end{array}$} & $\begin{array}{l}\text { Parastatal (both private and } \\
\text { public) }\end{array}$ & 27 & 38.00 \\
\hline & Private & 12 & 16.90 \\
\hline & Public & 32 & 45.10 \\
\hline \multirow[t]{5}{*}{ Highest educational degree held $(n=72)$} & $\mathrm{BSc}$ & 1 & 1.40 \\
\hline & Masters & 34 & 47.20 \\
\hline & Doctorate (practice-oriented) & 21 & 29.20 \\
\hline & $\mathrm{PhD}$ (research-oriented) & 15 & 20.80 \\
\hline & Other & 1 & 1.40 \\
\hline \multirow{3}{*}{$\begin{array}{l}\text { What kind of classes do you } \\
\text { usually teach? }(n=72)\end{array}$} & Face-to-face & 41 & 56.90 \\
\hline & $\begin{array}{l}\text { Hybrid (some online and } \\
\text { some face-to-face classes) }\end{array}$ & 28 & 38.90 \\
\hline & Online & 3 & 4.20 \\
\hline
\end{tabular}

Notes: One participant skipped the gender and type of higher education questions. This explains why $n=$ 71 for these characteristics

\section{Participants' characteristics}

The demographic characteristics for our sample of participating academics are summarised in Tables 1 and 2. From a total of 104 participants who responded partially or completely to our survey (discussed below in the section headed "Data collection"), 72 participants were retained. Participants who did not respond to more than $75 \%$ of the questions and those who were from other geographical regions than SIDS such as Europe were excluded from the analysis. As shown in Table 1, the final sample $(n=72)$ included academics who were on average 45.92 years old $(S D=10.53)$ with a mean of 15.22 years teaching in higher education and 12.34 years of experience in their current institution $(S D=8.56)$. 
As shown in Table 2, in terms of gender, there was a balanced representation in the study sample, with $52.11 \%$ women and $47.89 \%$ men. In terms of faculty discipline, a range of fields was represented, with more participants $(21 \%)$ from the social sciences than from other disciplines. In terms of geographical region, unsurprisingly, since we had tapped into our own peer networks, the largest group of our participants (45\%) came from the AIMS region. Thirty-two per cent of our participants worked in public universities, with a majority of $41 \%$ teaching face-to-face, and a total of $36 \%$ with terminal degrees. ${ }^{9}$

\section{Data collection}

To collect quantitative data, we conducted a survey with a larger sample of participants, and complemented this with qualitative data generated through semi-structured interviews with a subsample.

\section{Survey}

To gather information about participants' demographics (already presented above), their access to technology, their preparedness in terms of technology use, technology integration (multimedia use and pedagogy), change management and transformational leadership, we constructed a survey questionnaire divided into six main sections (see Table 3). We administered this survey online using SurveyMonkey. However, since the amounts of data collected were vast, i.e. beyond the scope of this article, we have decided to confine ourselves here to the access, preparedness and parts of the technology integration sections.

\section{Semi-structured interviews}

Extant research suggests that one thing which has typically constrained the use of technology in higher education in SIDS is a lack of leadership. Therefore, we decided to explore this issue further in semi-structured interviews to gauge whether the leadership of academic staff had helped our participants in their transition to online teaching. Applying a nested mixed methods strategy, we contacted a subsample of five academics by e-mail who indicated their consent to take part in followup semi-structured interviews and had high leadership scores. The leadership scores were calculated by adding the score on individual items in the leadership scale.

We conducted the interviews online using a semi-structured protocol designed to dig deeper into the actual lived experiences of the online transition during the COVID-19 lockdown. The protocol included two introductory questions about the respondents' background, and approximately eight questions about their experiences in shifting to online teaching. The main part of the interview centred on

\footnotetext{
9 A terminal degree is the highest available degree in a given academic discipline.
} 


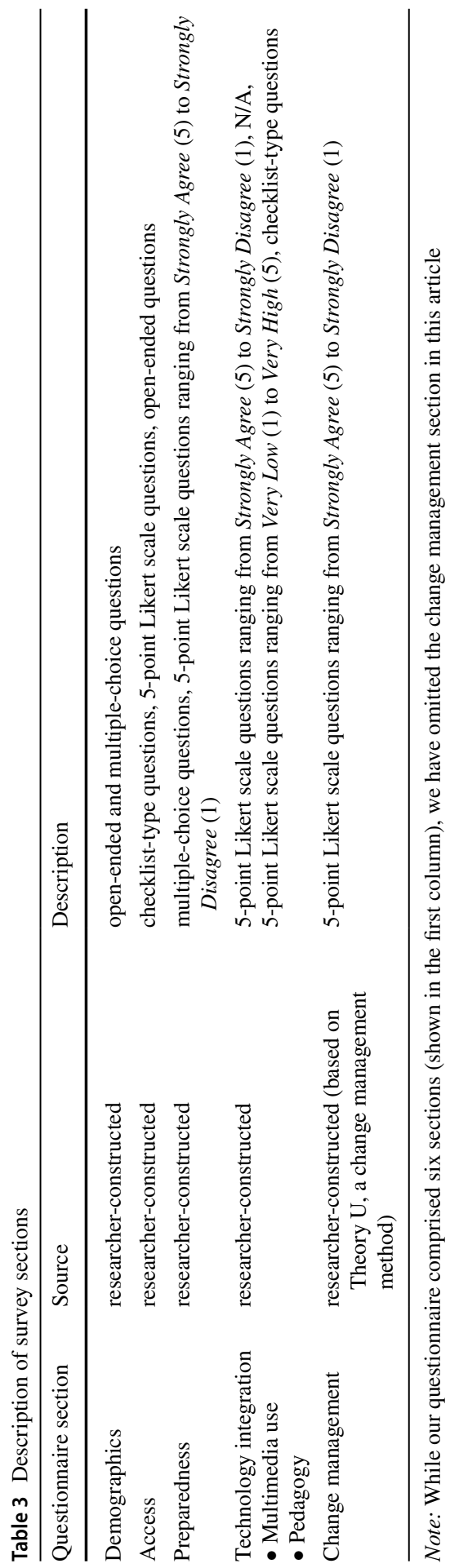


participants' leadership skills, their institutions' change management principles and priorities, and particularly their own use of technology in shifting to online teaching. The interviews (four in French and one in English) lasted between 25 and 35 minutes, were audio-recorded and transcribed verbatim by a research assistant after each interview session. Prior to each interview, we obtained a signed e-consent form from the interviewee stating that they agreed to participate in the interview and to be audio-recorded. All interviewees opted for audio-only interviews on Zoom (i.e. their cameras were switched off).

\section{Data analysis}

In our data analysis, we addressed Research Questions 1 and 2 quantitatively using descriptive and inferential statistics, which included principal component analysis (PCA) ${ }^{10}$ followed by multiple linear regressions (MLRs). We complemented these analyses qualitatively using interpretative phenomenological analysis (IPA) (Smith 1996). ${ }^{11}$ IPA was well-suited for our study because it emphasises an idiographic (individual) approach - examining each participant's lived teaching experiences; giving voice to participants' concerns, especially those who demonstrated a high level of leadership - "in relation to a wider social, cultural, and perhaps even theoretical context" (Larkin et al. 2006, p. 104).

We ensured face validity of our questionnaire by seeking feedback from an e-learning expert to assess the alignment of our constructs with our research objectives. In addition, we asked three academics and a non-academic to pretest our questionnaire to check understandability of our questions and overall usability of the online survey we had designed.

\section{Quantitative results}

Research Question 1 was: In what ways were academics in SIDS prepared for the transition to remote online teaching? We address this section by first presenting our findings for the factors of infrastructure, professional development and pedagogy. We then consider the psychometric properties of the scales (Efficacy, University Support and Educational Technologies Competencies), multiple linear regression and the moderating effects of experiences with online teaching.

\section{Infrastructure}

The first item in the survey section investigating "Access" was a checklist-type question which asked: "Which of the following tools and supports were you given by

\footnotetext{
${ }^{10}$ The purpose of principal component analysis is to structure, simplify and illustrate extensive data sets by reducing the number of variables while retaining as much information as possible.

11 The aim of interpretative phenomenological analysis is to provide detailed examinations of personal lived experiences and how each person makes sense of the events they go through.
} 


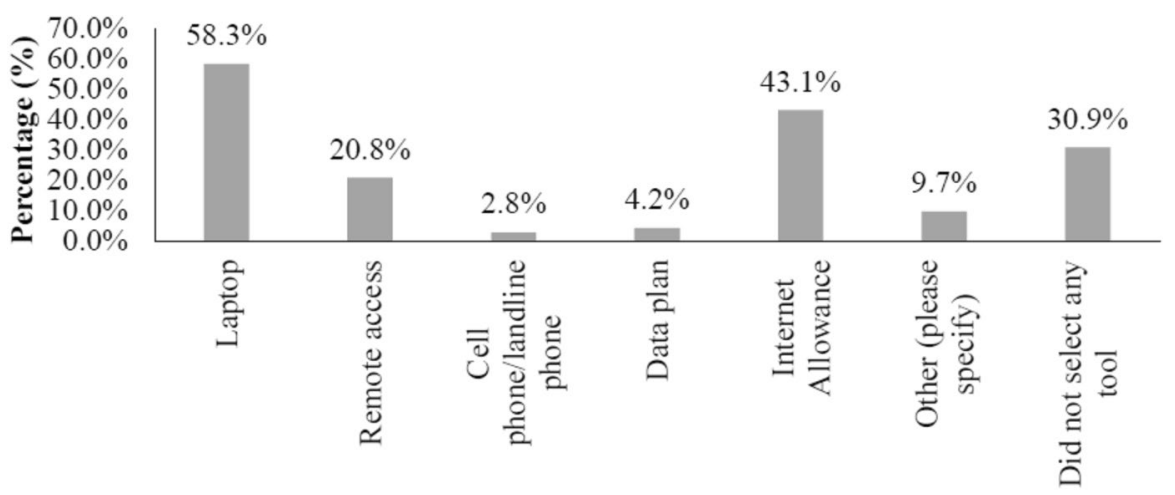

Tools and Support

Figure 2 Tools and support provided by the university for access during remote teaching

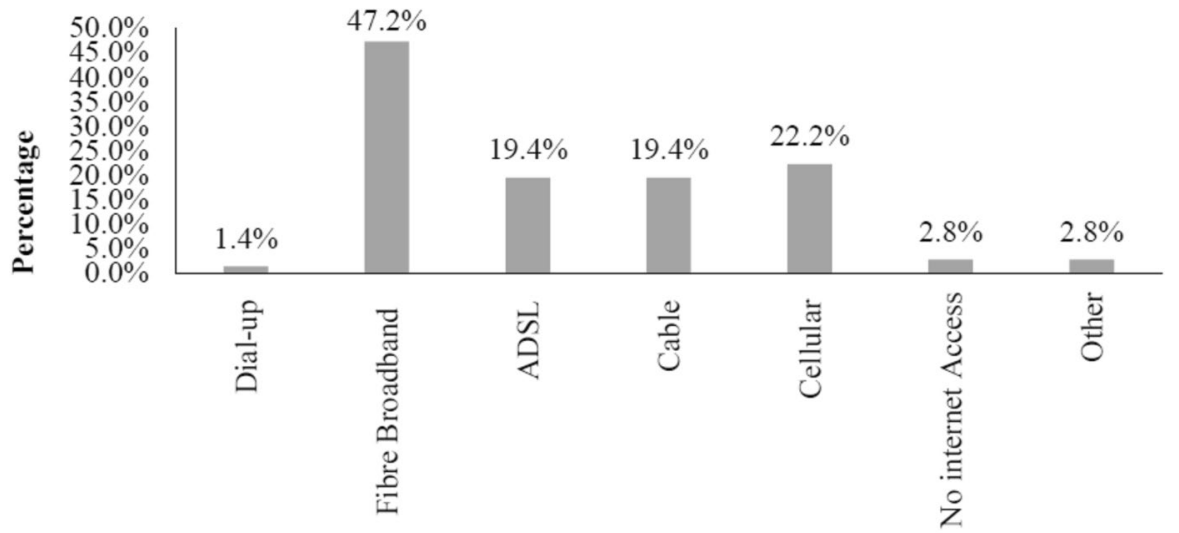

Type of Internet Connection

Figure 3 Type of internet connection

your institution to work from home?" The options in the checklist included laptop; remote access; cell phone/landline phone; data plan; internet allowance; and "other (please specify)". Figure 2 shows that more than half of the respondents (58\%) were provided with a laptop and $43.1 \%$ benefited from an internet allowance from their universities in their shift to working from home. In the "other" category, participants also mentioned the purchase of a Zoom (videoconferencing software) licence. Thirty per cent of respondents did not select any tools, implying that they either skipped the question or were not provided with any tools to support the emergency transition.

Another checklist-type question that was included in the "Access" section asked participants: "What type of internet connection do you have at home?" The responses to this question further informed our research team about how infrastructurally prepared our respondents were for emergency remote teaching. While $47.2 \%$ 


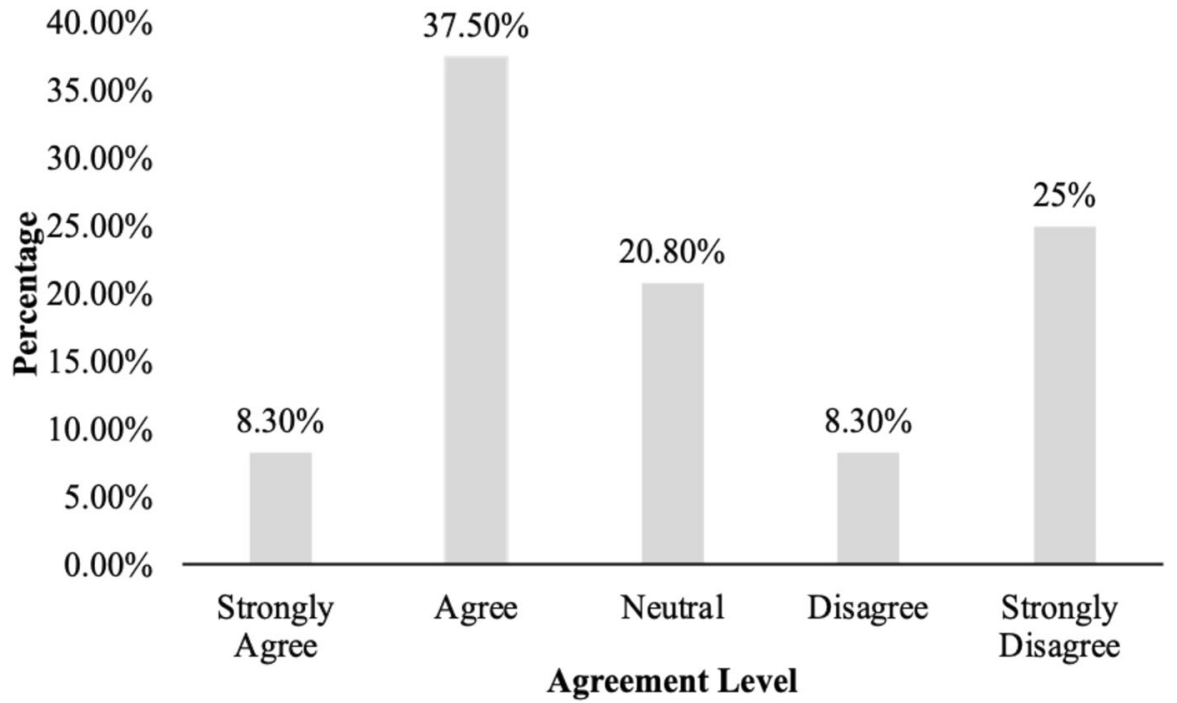

Figure 4 Adequate software access

of the academics had a fibre broadband connection (typically characterised by high internet speeds), a small percentage of respondents (1.4\%) had a dial-up connection, while $2.8 \%$ did not have any access to the internet (see Figure 3).

In our survey, we also asked participants to indicate their level of agreement to the question "To what extent did you have access to the software needed to teach online from home?" As shown in Figure 4, cumulatively, a higher percentage of academics (45.8\%), strongly agreed or agreed that they had access to the adequate software to teach online, compared to those (33.30\%) who disagreed and strongly disagreed.

\section{Professional development}

In the "Preparedness" section, we asked participants to indicate their agreement to the statements: "My university provided regular training on the use of educational technologies in teaching" and "The training I received was adequate". Although a total percentage of $41.6 \%$ of participants either strongly agreed or agreed that their university provided regular training on the use of educational technologies in teaching, only $26.4 \%$ acknowledged that the training was adequate (see Table 4). As shown in Table 4, recent training on using the tools needed for the shift to online teaching was largely perceived as scant, with $23.9 \%$ of the respondents disagreeing and $29.6 \%$ strongly disagreeing that they were provided with current training in using appropriate technological tools in preparation for teaching online from home. A dearth of instructional and administrative resources from the universities was also perceived cumulatively by close to half of the respondents. Out of the 72 participants, $18.1 \%$ disagreed and $27.8 \%$ strongly disagreed about being provided with resources. 


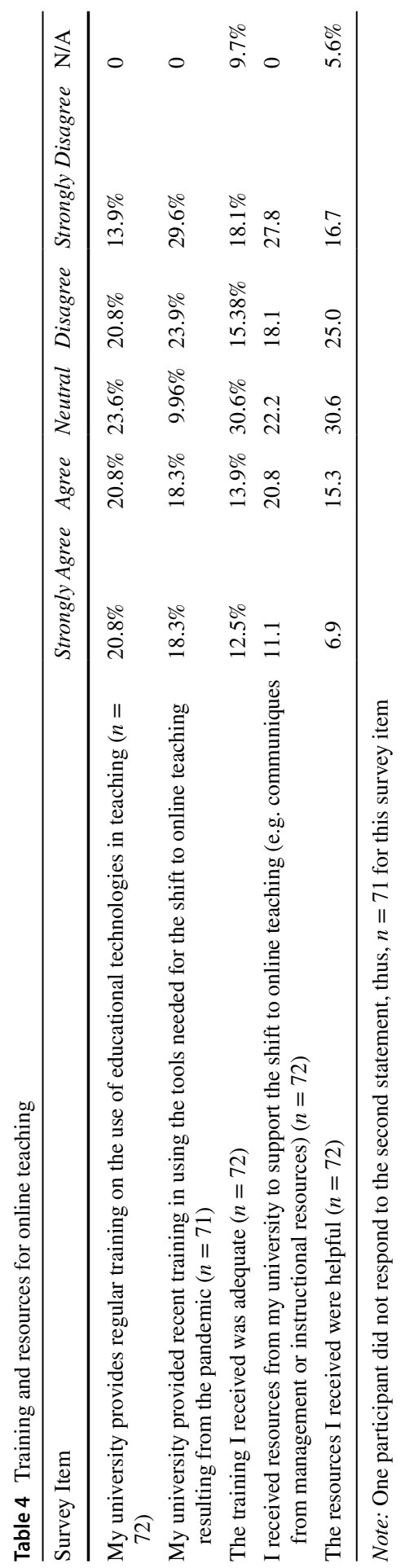


Table 5 Comfort level in using technological tools and software

\begin{tabular}{llllll}
\hline Tools and software & $N$ & Minimum & Maximum & $M$ & $S D$ \\
\hline E-mail & 71 & 2 & 5 & 4.52 & 1.09 \\
Word processing (e.g. Microsoft Word) & 72 & 2 & 5 & 4.46 & 1.14 \\
Presentations (e.g. PowerPoint) & 72 & 2 & 5 & 4.36 & 1.23 \\
Search engines (e.g. Google, Firefox) & 72 & 2 & 5 & 4.29 & 1.26 \\
Google Suite (e.g. Google Docs, Excel, etc.) & 72 & 1 & 5 & 3.42 & 1.41 \\
Videoconferencing (e.g. Zoom, Google Meet) & 72 & 1 & 5 & 3.42 & 1.39 \\
Database & 72 & 1 & 5 & 3.21 & 1.32 \\
Learning Management Systems & 72 & 1 & 5 & 3.21 & 1.49 \\
Social networking websites & 71 & 1 & 5 & 3.00 & 1.40 \\
Blogs & 71 & 1 & 5 & 2.87 & 1.34 \\
Wikis & 71 & 1 & 5 & 2.86 & 1.41 \\
\hline
\end{tabular}

Note: One participant did not respond to the survey statements asking about their comfort level in using social networking websites, blogs and wikis, thus, $n=71$

Participating academics' comfort level in using various tools and software in teaching online was analysed using descriptive statistics (see Table 5). Unsurprisingly, more academics indicated comfort in using e-mail $(M=4.52, S D=1.09)$ and word processing software $(M=4.46, S D=1.14)$ compared to other tools and software. Their mean comfort level in using videoconferencing software $(M=3.42, S D$ $=1.39)$ and team collaboration tools such as Google Suite $(M=3.42, S D=1.39)$ was quite similar, albeit relatively less than the traditional presentation, word processing and e-mail tools which are commonly used in the academic sphere. Our participant academics indicated the least comfort in using social networking websites, blogs $(M=2.87, S D=1.34)$ and wikis $(M=2.86, S D=1.41)$.

\section{Pedagogy}

Teaching online requires specific pedagogical approaches to keep the students engaged, motivate them to learn and create the best environment for deep learning. Respondents were asked to indicate, on a 5-point Likert scale, their level of agreement to the statements outlined in Table 6, which relate to instructional strategies they used in synchronous classes. Table 6 documents some of the strategies that were most popular among participant academics in the SIDS regions represented in our study. On average, more academics scaffolded their online classes by using a range of instructional tasks of varied complexity $(M=3.53, S D=1.33)$ and embedded collaboration within their classes $(M=3.31, S D=1.36)$ compared to the use of other strategies. However, the average number of participants agreeing that students were engaged in online sessions was relatively low. This suggests that, while instructors were equipped with sound knowledge of key pedagogical elements that make for better learning, such as collaboration and differentiation, a majority had not been able to engage learners in an online environment. 


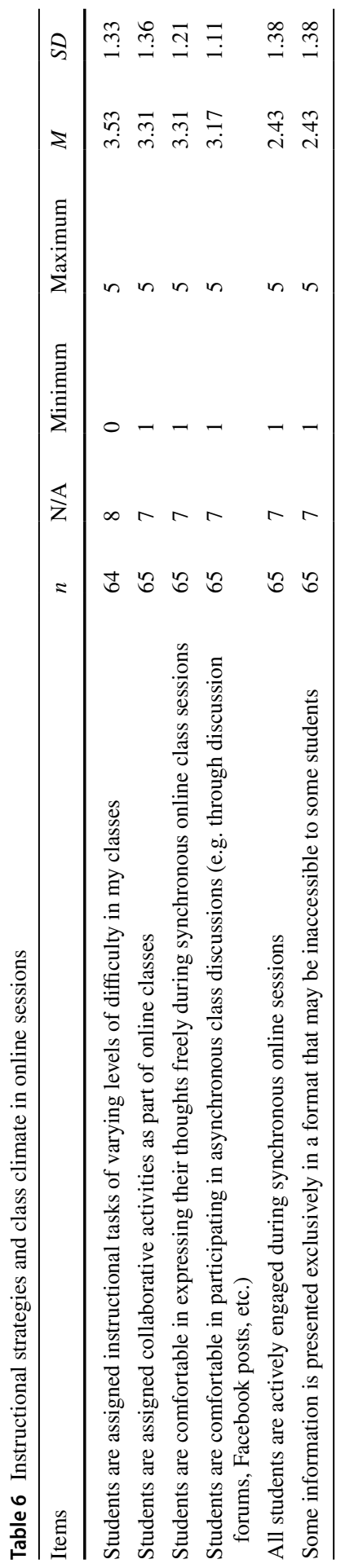


Research Question 2 was: How did preparedness for online teaching affect SIDS academics' efficacy in performing their work duties? In this study, efficacy is defined as academics' self-perceived ability to perform their work responsibilities such as grading despite the difficult professional conditions brought about by the pandemic. We drew on two sections of the survey, "Preparedness" and "Technology integration", to determine the preparedness and efficacy scales using principal component analysis before performing multiple linear regressions.

\section{Psychometric properties of the scales}

We tested the psychometric properties of the multi-item scales (work efficacy, university support, educational technologies competencies) using principal component analysis (PCA) and reliability analysis. Preliminary checks showed that the sample size was sufficient (KMO scores $>0.6)^{12}$ and intercorrelations between items were high enough (Bartlett's test of sphericity results, $p<.05$ ) for Principal Component Analysis. ${ }^{13}$ As a criterion for item retention, we used a threshold value of .4. The results are shown in Table 7.

With regard to the Efficacy scale, principal component analysis (PCA) suggested a unidimensional construct explaining $87.34 \%$ of variance. The construct contained three items with factor loadings ranging from .909 to .951 , well above the suggested cut-off point of .40 (Hair et al. 2006). For University Support, the PCA indicated that the component explained $74.08 \%$ of variance, with two items having loadings of .862 and .861, as shown in Table 7. Finally, for the Educational Technologies Competencies construct, three items were retained after three iterations. The latter explained $60.66 \%$ of variance.

The Cronbach alpha scores for Efficacy $(\alpha=0.918)$ and Educational Technologies Competencies $(\alpha=0.738)$ were both above the cut-off of .7 , indicating a sufficiently high level of internal consistency for those two scales (Hair et al. 2006). The Cronbach alpha score for the University Support scale $(\alpha=0.689)$ was lower than .7 , however, given that the scale comprised of only two items, a score above .6 is considered adequate (De Vellis 2016).

\section{Multiple linear regression}

We computed the composite scores for the three factors, i.e. the two dimensions of preparedness and the efficacy factor, based on the principal component analysis. The reliability measures for the scales we used in the regression are shown in Table 8.

\footnotetext{
12 KMO stands for Kaiser-Meyer-Olkin measure of sampling adequacy. It "is a statistic that indicates the proportion of variance in [the] variables that might be caused by underlying factors. High values (close to 1.0) generally indicate that a factor analysis may be useful with [the] data. If the value is less than 0.50 , the results of the factor analysis probably won't be very useful" (IBM 2014).

13 Bartlett's test of sphericity "tests the hypothesis that [the] correlation matrix is an identity matrix, which would indicate that [the] variables are unrelated and therefore unsuitable for structure detection. Small values (less than 0.05 ) of the significance level indicate that a factor analysis may be useful with [the] data" (IBM 2014).
} 


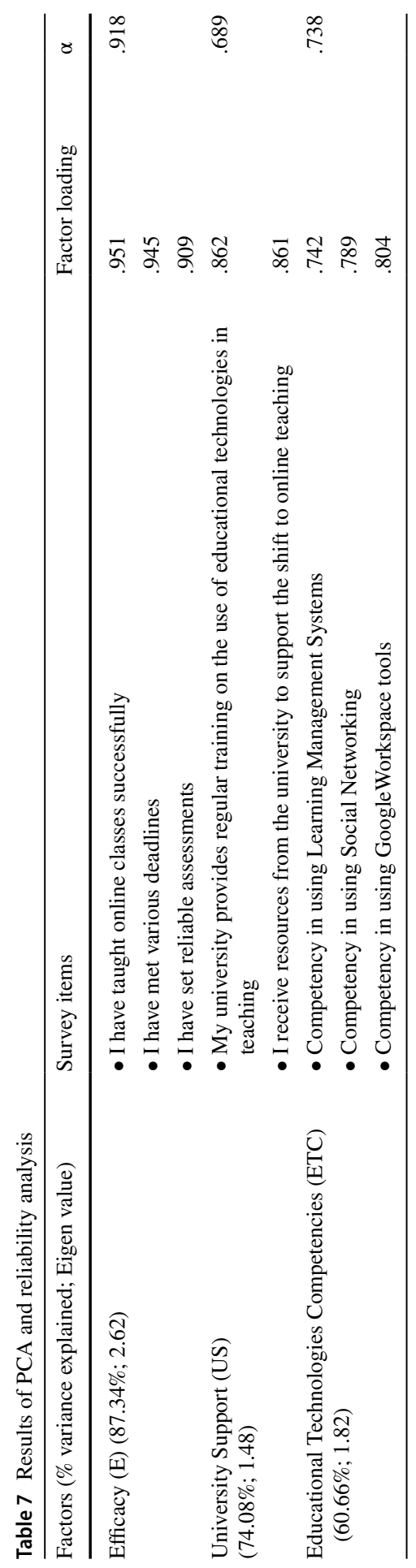


Table 8 Descriptive statistics and reliability measures for preparedness and efficacy measures

\begin{tabular}{lllr}
\hline Scale & Variables & $M$ & $S D$ \\
\hline Total Score Preparedness (Dimension 1: University Support) & 2 & 2.98 & 1.15 \\
$\begin{array}{l}\text { Total Score Preparedness (Dimension 2: Educational Technologies } \\
\quad \text { Competencies) }\end{array}$ & 3 & 3.30 & 1.12 \\
Total Score Efficacy & 3 & 4.22 & .87 \\
\hline
\end{tabular}

Table 9 Effects of preparedness dimensions on efficacy of academics in performing their work duties

\begin{tabular}{|c|c|c|c|c|c|c|c|c|}
\hline \multirow[t]{2}{*}{ Model } & \multicolumn{2}{|c|}{$\begin{array}{l}\text { Unstandardised } \\
\text { coefficients }\end{array}$} & \multirow{2}{*}{$\begin{array}{l}\text { Standard- } \\
\text { ised coef- } \\
\text { ficients } \\
\text { Beta }\end{array}$} & \multirow[t]{2}{*}{$t$} & \multirow[t]{2}{*}{ Sig. } & \multicolumn{2}{|c|}{$\begin{array}{l}\text { Collinearity } \\
\text { statistics }\end{array}$} & \multirow{2}{*}{$\begin{array}{l}\text { Model sum- } \\
\text { mary and } \\
\text { ANOVA } \\
\text { results }\end{array}$} \\
\hline & B & Std. Error & & & & Tolerance & VIF & \\
\hline (Constant) & 2.345 & 0.695 & & 3.374 & 0.001 & & & $\begin{array}{l}R^{2}=.19, \\
\text { adjusted } R^{2} \\
\quad=.14 \\
F(4,58)= \\
3.43 ; p< \\
0.05\end{array}$ \\
\hline University Support & 0.263 & 0.093 & $.344 * *$ & 2.84 & 0.006 & 0.952 & 1.051 & \\
\hline $\begin{array}{l}\text { Educational } \\
\text { Technologies } \\
\text { Competencies }\end{array}$ & 0.231 & 0.096 & $.291 *$ & 2.406 & 0.019 & 0.953 & 1.049 & \\
\hline Gender & -0.302 & 0.213 & -0.172 & -1.42 & 0.161 & 0.952 & 1.051 & \\
\hline Age & 0.01 & 0.01 & 0.118 & 0.977 & 0.333 & 0.959 & 1.043 & \\
\hline
\end{tabular}

$* p<.05 . * * p<.01$

The Cronbach's alpha value was greater than 0.8 across all the scales. The dependent variable we used in the multiple regression was Efficacy, which was defined as the ability for the academics to perform their duties. The main independent variables were University Support and Educational Technologies Competencies. We verified the assumptions of independence of residuals, multicollinearity, normality and homoscedasticity through examinations of a Durbin-Watson statistic, VIF values, ${ }^{14}$ normal probability plots, and a scatter plot of standardised residuals respectively. The Durbin-Watson statistic was 2.206 and VIF values ranged from 1.043 to 1.051, indicating an absence of autocorrelation of residuals and multicollinearity. Visual inspection of the probability plots and scatter plots of standardised residuals showed

\footnotetext{
14 Homoscedasticity refers to homogeneity of variance, meaning all the variables have the same finite variance. A Durbin-Watson statistic is a statistical test used to detect autocorrelation in the residuals from a regression analysis. Variance inflation factor (VIF) values are used to detect multicollinearity in regressions. Multicollinearity occurs due to correlation between independent variables in a model; its presence can adversely affect regression outcomes.
} 


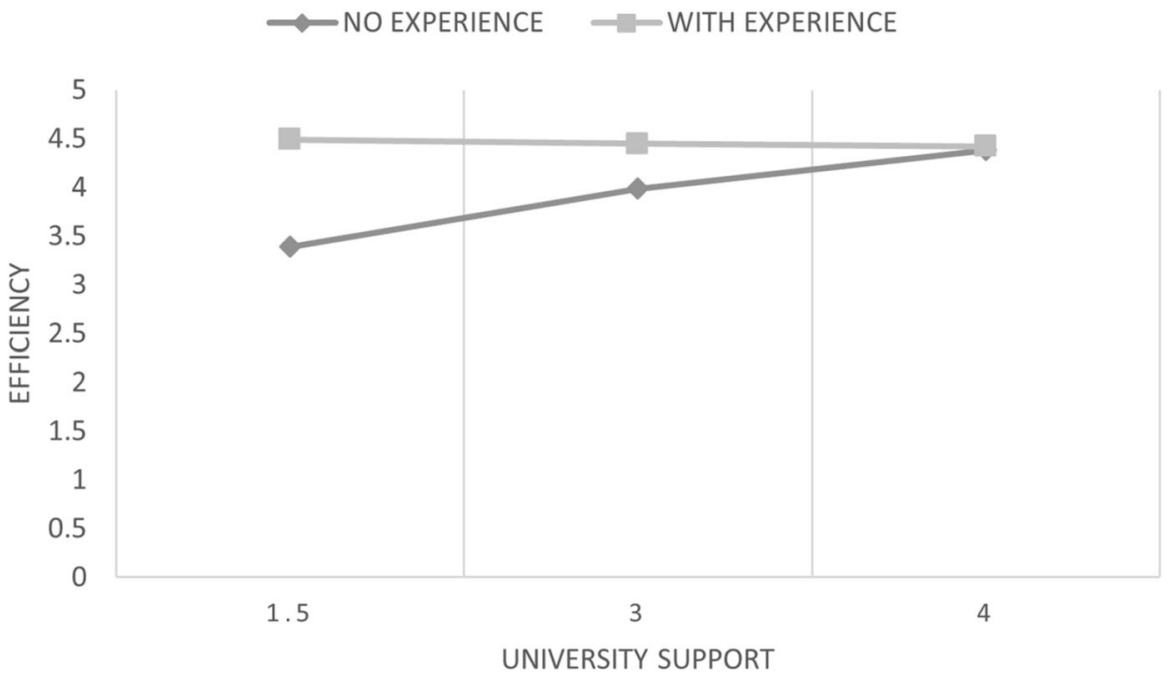

Figure 5 Moderating effects of online teaching experience. Notes: Experience refers to online teaching experience

no departure from normality and homoscedasticity. The results of the multiple linear regression analysis are summarised in Table 9.

The regression model was significant, $F(4,58)=3.43 ; p<.05$; adjusted $R^{2}=0.14$. The standardised regression coefficient $(\beta)$ values from Table 9 reported the importance of the predictive factors, with both University Support $(\beta=.263, p<.05)$ and Educational Technologies Competencies $(\beta=.231, p<.05)$ having statistically significant effects on the Efficacy of academics during the COVID-19 period. However, we found that two control variables, namely Gender $(\beta=-.172, p=0.161$, ns $)$ and Age $(\beta=.010, p=0.977, \mathrm{~ns})$ had no significant effect on Efficacy. The adjusted $R^{2}$ value of 0.14 shows that the two factors contributed $14.2 \%$ of the variance in the Efficacy of academics during the COVID-19 period.

\section{Moderating effects of experiences with online teaching}

The moderating effect of experience with online teaching was tested using Hayes' PROCESS $^{15}$ macro regression (see Figure 5). The results showed that experience with online teaching had a significant moderating effect on the relationship between University Support and Efficacy $(\beta=.-.425, p<.05)$. The results thus indicate that academics who had previous experience with online teaching did not depend as much on university support to exercise efficacy in their work when COVID-19-related measures brought face-to-face classes to a halt.

\footnotetext{
${ }^{15}$ PROCESS is a regression path analysis modelling tool created by quantitative methodologist Andrew F. Hayes (2017).
} 
Table 10 Demographic characteristics of interview participants

\begin{tabular}{llll}
\hline Interviewees & Gender & Age & Areas of Specialisation \\
\hline 1 & Male & 29 & Law and Management \\
2 & Female & 50 & Geography \\
3 & Female & 55 & Educational Leadership \\
4 & Male & 45 & Information Technologies \\
5 & Female & 32 & Environmental Law \\
\hline
\end{tabular}

\section{Qualitative results}

In accordance with our mixed methods strategy, we conducted the interviews following a semi-structured protocol. The demographic details of our five interviewees (a subsample of our survey cohort) are shown in Table 10.

To ensure accuracy, we circulated the interview transcripts to participants for member checks (review and approval). Next, one member of our research team read through each transcript without making annotations, and a second time making initial annotations in the margins. Transcripts were subsequently uploaded onto ATLAS-ti 8 (a software tool) for initial coding and memo-writing. Individually, two members of our research team read through the generated list and created clusters of inter-related codes per interview to describe the emergent themes. They then discussed solutions to any disagreements until consensus was reached. The data coding and subsequent thematic clustering from one transcript provided superordinate themes (uneven familiarity with technology, inadequate preparation for online teaching) which then emerged in the other transcripts, helping us to identify four main emerging themes: Uneven familiarity with technology; Inadequate preparation; Efficacy in dealing with multiple complex options; and Leadership from the top and the middle. Below, we discuss each of these in turn.

\section{Uneven familiarity with technology}

While most of the academics in our subsample were able to connect to e-learning tools and platforms, their degree of access was unequal due to the onerous handling of data packages or possible lack of technical support to get proper internet or Wi-Fi connections installed during the lockdown. In response to the question: "What significant technological challenges have you encountered during the shift to online teaching, and how did you cope with them?", one academic stated:

"I remember, like, my, one of my colleagues who is, like, quite old. And he used to call me ... he used to ask me, you know, how to use Zoom, how to use Google Classroom and, you know, 'Can I use your account?' And, I even gave my account to a colleague. So, that was another challenge, I gave my credentials to another colleague, because, you know, he was worried that he had to, you know, every time log in and out." 
The sharing of Zoom credentials, the juggling of technological tools, the mixing and matching of e-learning solutions demonstrate that academics' levels of access to and familiarity with using the technological tools needed to teach online were uneven.

\section{Inadequate preparation}

All our interviewees mentioned that many of their colleagues struggled in familiarising themselves with the tools required to deliver their online classes. The interviewees consistently reported a lack of preparedness as they compared their own level of technology integration with the experiences of their colleagues and students. In the case of one of the universities, where students studied part-time besides being frontline workers during COVID-19, the submission of assignments seemed a challenge, especially in switching from paper-based to online submission modes. Responding to the question: "When the confinement due to COVID-19 was announced, what were your first reactions?" and "How were the instructions for continuity of classes announced?", the academic from that particular university said:

“Actually there was a lot of panic. Because they didn't know, first of all, what will happen to the assignments, because they're generally used to sending the hard copy."

What also emerged from the interviews was that academics focused on emulating face-to-face classes through conferencing software such as Microsoft Teams, Zoom and Google Hangouts. While these tools allowed for real-time video interactions, they did not facilitate much learner engagement, as video cameras were switched off to allow for reduced bandwidth allocations. Where e-learning platforms were already in use, content delivery, feedback and learner engagement seemed to be better operationalised; however, the use of social media was limited and varied from group to group. One interviewee stated:

"But then we realised that most of the tutors, being aging people, they're not used to Facebook. Okay. So, we had to move towards alternatives. One alternative was WhatsApp."

\section{Efficacy in dealing with multiple complex options (every rose has its thorn)}

The following quote from one of the interviewees is particularly apt in summarising the confused situation that prevailed during the pandemic:

“... what lesson, the topic, what are the ... err, the platforms that they are going to use? Whether it is WhatsApp, whether it is mail, whether it is Google Classroom."

While trying to adapt to the complex situation, the universities did not prioritise one single solution for online teaching and learning. The tutors allowed students to use blends of e-learning platforms, communication and content production tools which ensured flexibility and learner-centredness. This proved to be additional work for the tutors and academics who had to juggle between various communication channels and 
online submission modes. For example, one interviewee discussed his effort of conducting classes for his students on Sundays and students' willingness to be flexible:

"... they are not against. Because for them, they wanted the semester to keep on running. They didn't want to lose the semester. So, this is why I say about thorns and roses, because on one side you have those who have differed, people who feel that they are not ready. Then, you have some who want, eventually, to attempt it."

\section{Leadership from the top and the middle}

Structures and processes put in place by universities prior to the pandemic provided both administrative and infrastructural opportunities for academics to exercise leadership during the health crisis. The individual needs of and constraints experienced by students were factored in and flexibility embedded within assessment systems, favouring a customised instructional approach

"Some of them said that they ... they were not willing to take it [exam], because they were not ready at all. Yes. So, the solution that was provided from our institution was that they were allowed to differentiate their modules [customise them to the students' individual learning needs]. And their marks for the continuous assessment."

It emerged from our interviews that some academics tried out novel techniques to reach out to their students. Autotelic (purpose-oriented) capabilities, or higher-order strategic thinking and efficacy that enabled improvisational selection and assembly of resources and skills (Karagouni and Caloghirou 2013) were clearly demonstrated by academics through their efforts to complete the semester syllabus and gear the learners for taking their examinations. When specifically asked: "What significant technological challenges have you encountered during the shift to online teaching, and how did you cope with them?" and also "What supports did you receive and would you have liked to receive?", responses were evasive and linked to self-directed techniques. Our interviewees adopted prototyping techniques, and one interviewee demonstrated self-efficacy in providing constructive solutions rather than aggravating the situation. In doing so, this academic acted as a role model who could inspire peers to drive change:

"we can, we should be self-dependent. And if the university is not giving any help, or our employer; I think we should do it ourselves because there are so many tutorials on YouTube that, you know, give you help on how to use these tools." 


\section{Discussion}

\section{In what ways were academics in SIDS prepared for the transition to remote online teaching?}

To answer the first research question, we examined academics' infrastructural readiness, their skillset in the use of educational technologies as well as the university support they received. For this, we drew on both the descriptive analysis of the quantitative data and qualitative analysis of the interviews.

The descriptive statistics were coherent with international figures reported by the World Bank (2020a), demonstrating increasing internet usage in the SIDS region. Only $2.8 \%$ of academics had no access to the internet and close to half, $47 \%$, had a fibre broadband connection, typically indicative of faster internet speeds. Furthermore, the majority of our respondents agreed that they had access to software needed to teach online. This suggests that SIDS have already made considerable progress in transcending the digital divide. Some participant academics, however, expressed concern that a minority of students lacked internet access or had slow internet speeds, which bears the potential of leading to digital exclusion trends (Bunyan and Collins 2013). Bandwidth issues prevented some students from using video, which impeded on the interactional quality of online classes, a trend reported worldwide (World Bank 2020b). Thus, although there is some evidence suggesting that academics working in SIDS-based universities were infrastructurally ready to teach online, some equity issues such as a minority of students' lack of access to high internet speeds remain.

Many of our participant academics felt a need to examine ways to make online teaching more inclusive, for example, by adopting multimodal approaches in seeking to achieve course objectives and better learning outcomes for their students (Mishra et al, 2020). This also shows that the traditional lecturing mode of dispensing information is not a viable solution for online teaching, as it is in contrast to online pedagogy. Preference should be given to more activity-based approaches with low technology requirements (Badiozaman et al. 2020; Crawford et al. 2020).

The lack of technical preparedness was also reflected in participants' lack of comfort in using some of the tools that can support online teaching. Unsurprisingly, a greater mean number of participants were comfortable in using traditional word processing and presentation software compared to collaborative document sharing tools, videoconferencing as well as social networking sites, blogs and wikis. These findings align with recent studies conducted in other parts of the world (Habib and Johannesen, 2014; Grajek and Rotman 2014; Porter and Graham 2016), which similarly highlight a need for universities to prioritise training tools and infrastructure that consolidate 21 st-century skills. Although more and more scholars are using social media for an array of professional activities such as instruction (Moran and Tinti-Kane 2013), our findings suggest that progress has been slow in SIDS. The moderately high power distance (Ramgutty-Wong 2004) characterising Mauritius, where most of our participants were from, is grounded 
in the country's colonial heritage. It has established status consciousness, which may act as a deterrent for lecturers to blur the lines between perceived professional and personal boundaries by connecting to students via social media.

Beyond a need to strengthen academics' technological competence, our findings also showed a need to bolster their proficiency in online pedagogy. Although many of our respondents tried to encourage synchronous collaboration and learner engagement through multimedia, discussions and scaffolding techniques, they perceived that students visibly lacked engagement. One of the reasons may be related to infrastructure, with students' poor bandwidth forcing them to keep their cameras/video function switched off. But as our qualitative findings also revealed, some SIDS academics were striving to replicate face-to-face teaching in an online environment, which may explain the lack of engagement that was perceived. While some elements of good teaching do cut across physical and virtual classrooms, online teaching also requires distinctive instructional strategies to promote engagement. Previous research carried out in Mauritius, where a majority of our participants were based, has identified a need for academics to move towards more social constructivist (knowledge construction through interaction with others)., connectivist (networking), and heutagogical (student-centred, self-determined) instructional approaches to promote student engagement (Ramkissoon et al. 2020). Gilly Salmon's e-tivities mentioned earlier (Salmon 2013) provide an appropriate framework which academics can use to promote more active online learner participation through a scaffolded approach, whereby learners receive more initial support which is gradually relinquished as they take greater ownership of their learning.

Our findings reveal that most SIDS-based universities provided basic resources (around 50\% academics had university-supplied laptops and internet allowances) for online teaching, although this support was not ubiquitous across all institutions. Less than half of the respondents (about 46\%) received regular educational technology training and even fewer found that this training was adequate (26.4\%). While ad hoc measures such as provision of some resources were put in place during COVID-19 to support academics in their shift to online teaching, those who had attended pre-pandemic educational technology training sessions were better prepared to effectively support their students. Training in both using technology and understanding its effective integration in the curriculum affects the implementation of educational technology (Harris et al. 2009), begging the inclusion of both elements in a programme of continuous professional development for academics to better prepare them for remote teaching, especially in emergency situations.

In sum, although our participant academics had access to communication tools and software, they perceived a lack of university support through ongoing and ad hoc training and were not adequately equipped with competencies in the technical and pedagogical use of a range of tools for online teaching.

\section{How did preparedness for online teaching affect SIDS academics' efficacy in performing their work duties?}

To address Research Question 2, we performed multiple linear regressions. Our regression model was statistically significant. Our two dimensions of 
preparedness, namely perceived University Support and Educational Technologies Competencies, had statistically significant effects on academics' efficacy. This aligns with Dawn Naylor and Julie Nyanjom's (2020) study which highlighted the negative impact of lack of institutional support on the emotional reactions of academics which can, in turn, hamper their ability to fulfil their professional responsibilities. Participants in our study reported limited support in the form of adequate training for online teaching. This is not surprising for two reasons: (1) up to now, universities in the SIDS region have typically placed little emphasis on online teaching, many early versions of which have carried the stigma of being inferior to face-to-face teaching; and (2) the conditions of haste and scant resources under which academics pivoted to online teaching left universities little time to provide adequate support.

Our study also reinforces the notion that knowledge of what constitutes good pedagogy in the physical classroom is not enough for successful online learning, which requires specific skills. Academics need to be equipped with relevant competencies so they can transform their pedagogy and adopt new roles, explore novel interactional modes and discover new ways of engaging students as they teach virtually (McLoughlin and Northcote 2017). Our study specifically brings to the fore the importance of academics' comfort level in using online educational tools as a determining factor affecting their ability to perform their duties effectively. This aligns with a study by Paula Mae Bigatel et al. (2012), which identified technological competence in terms of instructors' confidence in using tools as one of the skills needed to teach online successfully.

Our quantitative findings show that age did not have a significant effect on academics' efficacy. This does not discount the possibility that age may have some impact, as suggested by some of our interview participants. However, the impact may not be considerable enough to be statistically significant. The lack of effect suggests that academics in our sample, although of mean age of 44 and later career researchers, showed some resilience in fulfilling their core duties despite the disruptions brought about by the pandemic. Our regression also showed that gender did not impact efficacy significantly. This finding is reassuring, as it suggests that women teaching in SIDS-based universities are able to fulfil their work duties despite worldwide increases in women's homeschooling and caring responsibilities brought about by the pandemic (Adams-Prassl et al. 2020).

We found online teaching experience to be a moderator between university support and efficacy, that is, those who had prior experience were able to perform their duties and did not have to rely as much on university support. This finding is in line with previous studies which show that familiarity with and prior use of remote technologies contribute positively to perceptions of crisis preparedness (Gigliotti 2020) and are a source of self-efficacy (Bolliger et al. 2019) which can support academics in performing their duties. However, only $4 \%$ of the participants in our study stated that they typically taught online classes as part of their teaching journey, which underlines a need for significant university support as they transition to remote teaching during the pandemic. 


\section{Implications, limitations and future research}

Universities do not need to reimagine a novel education ecosystem overnight, but rather provide instructional support mechanisms that are easy to set up and available during the shift to emergency remote teaching and learning (Hodges et al. 2020). This can be in the form of short, targeted training, but, more importantly, "at-the-elbow" hotline support which can ease an otherwise strained transition to online teaching during a crisis. Consideration of our own findings in conjunction with Rapanta's tripartite framework of the social, cognitive and facilitatory presence of academics engaged in online teaching (Rapanta 2020) have allowed us to identify areas in which academics need training. Based on our findings in this study we contend that while the academics in our sample maintained satisfactory online social presence through various communication channels with learners, they needed training in (a) how to boost their cognitive presence through better consideration of students' engagement with the online learning contents; and (b) how to improve their facilitatory presence through increased intentionality and creativity in presenting content. Beyond the immediate ad hoc attempts to ensure learning continuity, our findings emphasise important long-term strategic implications for higher education in SIDS as well as practical implications for online teaching and learning in the region.

Health crises such as the COVID-19 pandemic that have taken a toll on tourism, have impacted the economies of individual SIDS countries dramatically, prompting various sectors such as higher education in an unprecedented way to interrogate traditional practices and develop strategies for resilience. SIDS countries are conceptualised as traditional and conservative. As suggested by our findings, they are attached to the traditional bricks-and-mortar university which is predominant in SIDS. Although our findings suggest that SIDS universities were able to maintain a semblance of teaching continuity by sharing resources and providing some guidance and tools, the teaching quality failed to engage students online. This is not unique to SIDS, as the conditions of haste and scant resources under which universities had to operate after the outbreak of the pandemic impeded teaching quality worldwide. However, the quality of online teaching needs to be addressed by higher education institutions to avoid loss of learning.

The responsibility for successful online teaching, however, should not be solely relegated to educational institutions. Our qualitative findings show that some academics who demonstrated high levels of efficacy took initiative to develop their digital skills independently and experiment with various tools. Whilst university leaders have a pivotal role to play in supporting high-quality online teaching within and beyond the pandemic, they do not have to do it on their own. Overcoming big challenges requires a truly concerted and collaborative effort. By embedding leadership development into training efforts targeting academics, universities can equip them with the skills they need to persevere in challenging times and become genuine partners in the universities' continuity and success. By shaping academics as leaders, universities can reduce overreliance on formal training, which may be challenging to provide effectively during the conditions of 
a pandemic or other emergency. To encourage academics to demonstrate leadership behaviour, universities also need to provide recognition for initiative taking and autotelic approaches for more efficacy. We contend that a balanced mix of independent learning and customised and targeted formal professional learning would provide the ideal recipe for greater preparedness for online teaching and hence work efficacy.

The current research saw greater participation from SIDS in the AIMS region. More data must be gathered from other SIDS countries for a more comprehensive understanding of the levels of preparedness of SIDS-based academics for emergency online teaching. While investigation of the preparedness of academics for online teaching is an important area of research, it is also pivotal to understanding students' readiness for and agency in multimodal learning so that appropriate support strategies can be devised. The current study examined the individual preparedness of academics; however, future research might focus on external factors at the macro level such as institutional and governmental policies which are likely to have impacted academics' efficacy as well.

\section{References}

Adams-Prassl, A. T., Boneva, M. G., \& Rauh, C. (2020). Inequality in the impact of the Coronavirus shock: Evidence from real time surveys. Journal of Public Economics, 189, 104245. https://doi. org/10.1016/j.jpubeco.2020.104245.

Atlantis Group. (2020). COVID-19 represents most significant challenge to education since WW2. Varkey Foundation, 29 April [online opinion piece]. Retrieved 7 April 2021 from https:// www.varkeyfoundation.org/opinion/covid-19-represents-most-significant-challenge-to-educa tion-since-ww2/.

Azevedo, J. P., Hasan, A., Goldemberg, D., Iqbal, S. A., \& Geven, K. (2020). Simulating the potential impacts of COVID-19 school closures on schooling and learning outcomes: A set of global estimates. Conference edn. Washington, DC: World Bank. Retrieved 7 April 2021 from http://pubdocs. worldbank.org/en/798061592482682799/covid-and-education-June17-r6.pdf.

Badia, A., Garcia, C., \& Meneses, J. (2017). Approaches to teaching online: Exploring factors influencing teachers in a fully online university. British Journal of Educational Technology, 48(6), 1193-1207. https://doi.org/10.1111/bjet.12475.

Badiozaman, I. F. A., Leong, H. J., \& Wong, W. (2020). Embracing educational disruption: A case study in making the shift to a remote learning environment. Journal of Applied Research in Higher Education, online first.. https://doi.org/10.1108/jarhe-08-2020-0256.

Bao, W. (2020). COVID-19 and online teaching in higher education: A case study of Peking University. Human Behavior and Emerging Technologies, 2(2), 113-115. https://doi.org/10.1002/hbe2.191.

Bates, A. W. (2020). Advice to those about to teach online because of the corona-virus. Online Learning and Distance Education Resources, 9 March [blog post]. Retrieved 3 April 2020 from https://www. tonybates.ca/2020/03/09/advice-to-those-aboutto-teach-online-because-of-the-corona-virus/.

Bigatel, P. M., Ragan, L. C., Kennan, S., May, J., \& Redmond, B. F. (2012). The identification of competencies for online teaching success. Online Learning, 16(1), 59-77. https://doi.org/10.24059/olj. v16i1.215.

Bolliger, D. U., Shepherd, C. E., \& Bryant, H. V. (2019). Faculty members' perceptions of online program community and their efforts to sustain it. British Journal of Educational Technology, 50(6), 3283-3299. https://doi.org/10.1111/bjet.12734.

Bonk, C. J., \& Wiley, D. A. (2020). Preface: Reflections on the waves of emerging learning technologies. Educational Technology Research and Development, 68(4), 1595-1612. https://doi.org/10.1007/ s11423-020-09809-x. 
Bunyan, S., \& Collins, A. (2013). Digital exclusion despite digital accessibility: Empirical evidence from an English city. Journal of Economic and Social Geography, 104(5), 588-603. https://doi.org/10. 1111/tesg.12047.

Chandra, R. (2010). Harnessing technology for tertiary education in small island developing states (SIDS). IIEP Policy Brief Tertiary Education in Small States, no. 3. Paris: United Nations Educational, Scientific and Cultural Organization, International Institute for Educational Planning (UNESCO-IIEP). Retrieved 7 April 2021 from https://unesdoc.unesco.org/ark:/48223/pf0000218986.

Crawford, J., Butler-Henderson, K., Rudolph, J., Malkawi, B., Glowatz, M., Burton, R., Magni, P. A., \& Lam, S. (2020). COVID-19: 20 countries' higher education intra-period digital pedagogy responses. Journal of Applied Learning \& Teaching, 3(1), 9-28. https://doi.org/10.37074/jalt.2020.3.1.

Creswell, J. W. (2013). Qualitative inquiry and research design: Choosing among five approaches (3rd ed.). Thousand Oaks, CA: SAGE Publications Inc.

Crossley, M., \& Sprague, T. (2014). Education for sustainable development: Implications for small island developing states (SIDS). International Journal of Educational Development, 35, 86-95. https://doi. org/10.1016/j.ijedudev.2013.03.002.

Czerniewicz, L. (2020). University shutdowns: What we learnt from "going online". University World News, 31 March [online article]. Retrieved 7 April 2021 from https://www.universityworldnews. com/post.php?story=20200325160338881.

De Vellis, R. F. (2016). Scale development: Theory and applications. Thousand Oaks, CA: Sage Publications.

Downing, J. J., \& Dyment, J. E. (2013). Teacher educators' readiness, preparation, and perceptions of preparing preservice teachers in a fully online environment: An exploratory study. The Teacher Educator, 48(2), 96-109. https://doi.org/10.1080/08878730.2012.760023.

Dutta, S. \& Jain, A. (2004). The networked readiness index 2003-2004: Overview and analysis framework. In S. Dutta, B. Lanvin \& F. Paua (Eds.), The global information technology report 20032004: Towards an equitable information society (pp. 3-22). New York, NY: Oxford University Press. Retrieved 7 April 2021 from http://documents.worldbank.org/curated/en/825291468175149 560/pdf/343090GITR2003.pdf.

Edris, D. D. (2020). Identifying strategies for preparing and supporting Florida college students in eLearning: Case study of a Florida public state college's student success in eLearning. Doctoral thesis, Florida Atlantic University.

Feist, D., \& Reid, D. (2017). Technology and teaching: Technology and student-centered pedagogy in 21 st-century classrooms. In J. Keengwe (Ed.), Handbook of research on digital content, mobile learning, and technology integration models in teacher education (pp. 69-87). Hershey, PA: IGI Global.

Fook, C. Y., Sidhu, G. K., Kamar, N., \& Abdul, N. (2011). Pre-service teachers' training in information communication and technology for the ESL classrooms in Malaysia. Turkish Online Journal of Distance Education, 12(3), 97-108.

Gigliotti, R. A. (2020). Sudden shifts to fully online: Perceptions of campus preparedness and implications for leading through disruption. Journal of Literacy \& Technology, 21(2), 18-36. http://www. literacyandtechnology.org/uploads/1/3/6/8/136889/j1t_vol_21_2_v1.02.pdf.

Grajek, S., \& Rotman, D. (2014). Top-ten IT issues, 2014: Be the change you see. Educause Review, 49(2), 10-54.

Guillaumont, P. (2010). Assessing the economic vulnerability of small island developing states and the least developed countries. The Journal of Development Studies, 46(5), 828-854. https://doi.org/10. $1080 / 00220381003623814$.

Gurley, L. E. (2018). Educators' preparation to teach, perceived teaching presence, and perceived teaching presence behaviors in blended and online learning environments. Online learning, 22(2), 197220. https://doi.org/10.24059/olj.v22i2.1255.

Gülbahar, Y., \& Adnan, M. (2020). Faculty professional development in creating significant teaching and learning experiences online. In L. Kyei-Blankson, E. Ntuli, \& J. Blankson (Eds.), Handbook of research on creating meaningful experiences in online courses (pp. 37-58). Hershey, PA: IGI Global.

Habib, L., \& Johannesen, M. (2014). Perspectives on academic staff involvement in the acquisition and implementation of educational technologies. Teaching in Higher Education, 19(5), 484-496. https:// doi.org/10.1080/13562517.2014.880679.

Hair, J., Black, W., Babin, B., Anderson, R., \& Tatham, R. (2006). Multivariate data analysis (6th ed.). Upper Saddle River, NJ: Pearson Education. 
Harris, J., Mishra, P., \& Koehler, M. J. (2009). Teachers' technological pedagogical knowledge and learning activity types: Curriculum-based technology integration reframed. Journal of Research on Technology in Education, 41(4), 393-416. https://doi.org/10.1080/15391523.2009.10782536.

Hayes, A. F. (2017). Introduction to mediation, moderation, and conditional process analysis: A regression-based approach. New York, NY: Guilford Press.

Henrikson, A. K. (2001). A coming "Magnesian" age? Small states, the global system, and the international community. Geopolitics, 6(3), 49-86. https://doi.org/10.1080/14650040108407729.

Herrington, J., Reeves, T. C., \& Oliver, R. (2010). A guide to authentic e-learning. New York, NY: Routledge. https://doi.org/10.4324/9780203864265.

Hodges, C., Moore, S., Lockee, B., Trust, T., \& Bond, A. (2020). The difference between emergency remote teaching and online learning. Educause Review, 27 March [online article]. Retrieved 7 April 2021 from https://er.educause.edu/articles/2020/3/the-difference-between-emergency-remote-teach ing-and-online-learning.

IBM. (2014). KMO and Bartlett's Test. In IBM Documentation, Using factor analysis for structure detection [online resource]. Retrieved 19 April 2021 from https://www.ibm.com/docs/en/spss-statistics/ 23.0.0?topic $=$ detection-kmo-bartletts-test.

ITU (International Telecommunications Union). (2019). Small Island Developing States (SIDS) and ICTs: Mid-term review of the Samoa pathway. Geneva: ITU. Retrieved 7 April 2021 from https:// www.itu.int/pub/D-LDC-SIDS_SAMOA.01-2019.

Jones, J. G. (2008). Issues and concerns of directors of postsecondary distance learning programs regarding online methods and technologies. The American Journal of Distance Education, 22(1), 46-56. https://doi.org/10.1080/08923640701713430.

Kanwar, A., \& Daniel, J. (2020). Report to Commonwealth education ministers: From response to resilience. Burnaby, BC: Commonwealth of Learning. Retrieved 7 April 2021 from http://oasis.col.org/ handle/11599/3592.

Karagouni, G., \& Caloghirou, Y. (2013). The nature and dimensions of autotelic capabilities in knowledge-intensive low-tech ventures: an introduction. World Review of Entrepreneurship, Management and Sustainable Development, 9(2), 230-245. https://doi.org/10.1504/WREMSD.2013.052361.

Kilgour, P., Reynaud, D., Northcote, M., McLoughlin, C., \& Gosselin, K. P. (2019). Threshold concepts about online pedagogy for novice online teachers in higher education. Higher Education Research \& Development, 38(7), 1417-1431. https://doi.org/10.1080/07294360.2018.1450360.

Koh, J. H. L., Herring, S. C., \& Hew, K. F. (2010). Project-based learning and student knowledge construction during asynchronous online discussion. The Internet and Higher Education, 13(4), 284291. https://doi.org/10.1016/J.IHEDUC.2010.09.003.

Lackey, K. (2011). Faculty development: An analysis of current and effective training strategies for preparing faculty to teach online. Online Journal of Distance Learning Administration, 14(4), 1-27.

Lane, C. A., \& Lyle, H. F. (2011). Obstacles and supports related to the use of educational technologies: The role of technological expertise, gender, and age. Journal of Computing in Higher Education, 23(1), 38-59. https://doi.org/10.1007/s12528-010-9034-3.

Larkin, M., Watts, S., \& Clifton, E. (2006). Giving voice and making sense in interpretative phenomenological analysis. Qualitative Research in Psychology, 3(2), 102-120. https://doi.org/10.1191/14780 88706qp062oa.

Luthra, P. \& Mackenzie, S. (2020). 4 ways COVID-19 could change how we educate future generations. World Economic Forum, 30 March [online article]. Retrieved 7 April 2021 from https://www.wefor um.org/agenda/2020/03/4-ways-covid-19-education-future-generations/.

Mansbach, J., \& Austin, A. E. (2018). Nuanced perspectives about online teaching: Midcareer and senior faculty voices reflecting on academic work in the digital age. Innovative Higher Education, 43(4), 257-272. https://doi.org/10.1007/S10755-018-9424-4.

McLoughlin, C., \& Northcote, M. (2017). What skills do I need to teach online? Researching experienced teacher views of essential knowledge and skills in online pedagogy as a foundation for developing professional development. In J. Mena, A. García-Valcárcel, F.J. García Peñalvo, M. Martín del Pozo (Eds.), Search and research: Teacher education for contemporary contexts. Proceedings of the 18th Biennial Conference on Teachers and Teaching, held 3-7 July 2017 at the University of Salamanca, Spain. (pp. 1119-1129). Salamanca: Ediciones Universidad de Salamanca.

Mishra, L., Gupta, T., \& Shree, A. (2020). Online teaching-learning in higher education during lockdown period of COVID-19 pandemic. International Journal of Educational Research Open, 1, 100012. https://doi.org/10.1016/j.ijedro.2020.100012. 
Moran, M., \& Tinti-Kane, H. (2013). Social media for teaching and learning. Boston, MA: Pearson Learning Solutions. Retrieved 7 April 2021 from https://onlinelearningsurvey.com/reports/socialmedia-for-teaching-and-learning-2013-report.pdf.

Naylor, D., \& Nyanjom, J. (2020). Educators' emotions involved in the transition to online teaching in higher education. Higher Education Research \& Development, online first.. https://doi.org/10.1080/ 07294360.2020 .1811645 .

Porter, W. W., \& Graham, C. R. (2016). Institutional drivers and barriers to faculty adoption of blended learning in higher education. British Journal of Educational Technology, 47(4), 748-762. https:// doi.org/10.1111/bjet.12269.

Ramgutty-Wong, A. (2004). HRM in Mauritius. In K. N. Kamoche, Y. A. Debrah, F. N. Horwitz, \& G. N. Muuka (Eds.), Managing human resources in Africa (pp. 53-68). London: Routledge.

Ramkissoon, P., Belle, L. J., \& Bhurosy, T. (2020). Perceptions and experiences of students on the use of interactive online learning technologies in Mauritius. International Journal of Evaluation and Research in Education, 9(4), 833-839. https://doi.org/10.11591/ijere.v9i4.20692.

Rapanta, C., Botturi, L., Goodyear, P., Guàrdia, L., \& Koole, M. (2020). Online university teaching during and after the COVID-19 crisis: Refocusing teacher presence and learning activity. Postdigital Science and Education, 2(3), 923-945. https://doi.org/10.1007/s42438-020-00155-y.

Richter, S., \& Idleman, L. (2017). Online teaching efficacy: A product of professional development and ongoing support. International journal of nursing education scholarship, 14(1), 20160033. https:// doi.org/10.1515/ijnes-2016-0033.

Rumbley, L. E. (2020). Coping with COVID-19: International higher education in Europe. Amsterdam: European Association for International Education (EAIE) Retrieved 7 April 2021 from https://www. eaie.org/our-resources/library/publication/Research-and-trends/Coping-with-COVID-19-Internatio nal-higher-education-in-Europe.html.

Salmon, G. (2013). E-tivities: The key to active online learning (2nd ed.). London/New York: Routledge.

Self, D. R., \& Schraeder, M. (2009). Enhancing the success of organizational change: Matching readiness strategies with sources of resistance. Leadership \& Organization Development Journal, 30(2), 167-182. https://doi.org/10.1108/01437730910935765.

Smith, J. A. (1996). Beyond the divide between cognition and discourse: Using interpretative phenomenological analysis in health psychology. Psychology and Health, 11(2), 261-271. https://doi.org/ $10.1080 / 08870449608400256$.

United Nations (2014). Third International Conference on Small Island Developing States, 1-4 September 2014, Apia, Samoa [dedicated webpage]. Retrieved 14 April 2021 from https://www.un.org/en/ conferences/small-islands/apia2014.

Weissman, S. (2020). Diverse webinars explore new questions facing higher education amid COVID-19. Diverse: Issues in Higher Education, 37(6), 26-28.

Weller, M. (2020). The COVID-19 online pivot: Adapting university teaching to social distancing. LSE Impact Blog, 12 March [blog post]. Retrieved 7 April 2021 from https://blogs.lse.ac.uk/impactofso cialsciences/2020/03/12/the-covid-19-online-pivot-adapting-university-teaching-to-social-dista ncing/.

World Bank (2020a). Individuals using the Internet (\% of population) 1990-2019. International Telecommunication Union (ITU) World Telecommunication/ICT Indicators Database [online database]. Retrieved 26 April 2021 from https://data.worldbank.org/indicator/IT.NET.USER.ZS.

World Bank (2020b). How countries are using edtech (including online learning, radio, television, texting) to support access to remote learning during the COVID-19 pandemic [online edutech brief]. Retrieved 26 April 2021 from https://www.worldbank.org/en/topic/edutech/brief/how-countries-areusing-edtech-to-support-remote-learning-during-the-covid-19-pandemic.

Publisher's Note Springer Nature remains neutral with regard to jurisdictional claims in published maps and institutional affiliations.

Isma Seetal worked as a Chemistry teacher at Northfields International School in her home country, Mauritius, for 7.5 years before transitioning into a school principal position in a newly founded alternative school where she worked for about 8 months. As a recipient of a Rotary Global Grant, she embarked on an EdD in Educational Leadership at Concordia University Irvine in the United States, where she 
worked as a graduate research assistant and carried out research in the area of educational leadership and educational equity. She has worked as a course developer and an online lecturer for the Australian Education Management Group (AEMG). She currently works as a senior education developer at Deakin University in Australia.

Sandhya Gunness is a senior lecturer at the Centre for Innovative and Lifelong Learning - University of Mauritius. She is the online tutor and content developer for the BSc and MSc Educational Technology Programmes in the fields of open educational practices; social networking; principles of learning design and ICT integration for Science and Technology education. She is also coordinating the MA Educational Leadership programme in collaboration with the University of Seychelles. She has worked with the Commonwealth of Learning (COL), the United Nations Educational, Scientific and Cultural Organization (UNESCO), the Common Market for Eastern and Southern Africa (COMESA) and the Southern African Development Community (SADC) on numerous e-learning projects and is currently pursuing her $\mathrm{PhD}$ studies in the field of Horizontal Collaborative Networks and development of T-shaped graduates through transdisciplinary educational practices.

Viraiyan Teeroovengadum $\mathrm{PhD}$, is a senior lecturer at the University of Mauritius. His primary research interests are in the fields of higher education, quality assurance and services marketing. He holds a $\mathrm{PhD}$ in Quality Management, a Master's degree in Educational Leadership and Management, and is a graduate in Law and Management. He has published in various respected academic journals such as European Business Review, Quality Assurance in Education and Journal of Contemporary Hospitality Management. While being well-versed in both quantitative and qualitative methods, he has a keen interest in statistical modelling and psychometrics.

\section{Authors and Affiliations}

\section{Isma Seetal $^{1}$ (D) . Sandhya Gunness ${ }^{2}$. Viraiyan Teeroovengadum ${ }^{2}$}

Sandhya Gunness

s.gunness@uom.ac.mu

Viraiyan Teeroovengadum

v.teeroovengadum@uom.ac.mu

1 Mount Waverley, VIC 3002, Australia

2 University of Mauritius, Reduit 80837, Mauritius 